\title{
Antimicrobial Activity of Petroleum Ether, Ethylacetatate and Methanolic Fraction of Five Sudanese Medicinal Plant
}

\author{
Bader Omer Burham \\ Chemistry Department, Faculty of Science, Albaha University, Albaha, Saudi Arabia
}

\begin{abstract}
Five medicinal plants (Acanthospermum hispidum, Achyranthus aspera, Ambrosia maritima, Combretum hartmannianum and Commiphora myrrh) were shade dried, grinded and extracted with different solvents according to the increasing polarity, petroleum ether, ethyl acetate and Methanol. All the dried extract were tested for their antimicrobial activity against four standard strains, two Gram positive Staphylococcus aureus, Bacillus subtilis, and two Gram negative bacterial strains Escherichia coli, Pseudomonas aeruginosa, and against two fungal strains Aspergillus niger and Candida albicans. in vitro, using the agar well diffusion method. The crude extracts showed varying level of bactericidal activity at the higher cocentration (100 mg/well). The highest antibacterial activity was found in methanolic extracts and lowest in the petroleum ether fraction. Combretum hartmannianum showed broad spectrum of antimicrobial activity, and produced the highest zone of inhibition against all the tested Gram-negative and Gramposivive bacteria, with maximum activity observed against Bacillus subtilis (IZ $=35 \mathrm{~mm})$. Other plant crude extracts were active against different bacterial strains. The methanolic, ethyl acetate and petroleum ether fraction of C. hartmannianum are suitable candidates for the development of novel antibacterial herbal formulation. Photochemical screening of methanolic extracts of $C$. hartmannianum was performed for the various constituents: flavonoids, saponins, tannins, alkaloids, essential oils and terpens. The results of TLC analysis of C. hartmannianum extracts were shown as $R_{f}$ values for saponins, essential oils, flavonoids and tannins.
\end{abstract}

Keywords: Antimicrobial, Phytochemical, medicinal plants, secondary metabolites

\section{Introduction}

Antimicrobial agents are naturally occurring, semi-synthetic and synthetic compounds with antimicrobial activity that are used in human and veterinary medicine to prevent and treat infections and for growth promotion in food animals. The growth-promoting effects of antimicrobial agents were first discovered in the 1940s when chickens fed by-products of tetracycline fermentation were found to display increased growth rates (1). Since then, many antimicrobial agents have been found to improve average daily weight gain and feed efficiency in livestock in a variety of applications (2).

Whereas some growth-promoting effects are mediated through alterations of the normal intestinal microbial resulting in more efficient digestion of feed and metabolism of nutrients, others are mediated through the immune system release resulting from suppression of non-resistant pathogens $(3,4)$.

This new trend was supported by: The recent WHO orientation strategy that embarked on examination of the historical position of traditional medicine at their intersections with the development and modernization of a bio medically-based health care system (5. 6).

Some plants are known as medicinal because they contain active substances that have certain interaction with the bio molecules, which result into the cure of disease (7). Knowledge on medicinal plants sometimes means the only therapeutic resource of some communities and ethnic groups (8), and their use especially in South America contributes significantly to primary health care (9).
The antimicrobial activities of medicinal plants can be attributed to the secondary metabolites such as flavonoids, terpenoids, tannins, alkaloids that are present in the plants (10). These plants are used by the Sudanese local people to nourish the sheep and chicken. It has also been used as an ingredient in local medicine for several ailments. The use of the medicinal plants as anti-infective agent is very well documented (11), tested 114 extracts of 35 Sudanese plants for their antibacterial activity against four different bacterial species, using the cup-plate agar diffusion method.

A. hispidum were carried out to evaluate phytotoxic effects of pure organic acid solutions (12). The ethanolic extract of Achyranthes aspera caused reproductive toxicity in male rats and the action may be by suppressing the synthesis of androgen, (13). There was no further cardiac abnormalities noted in serial cardiac examinations. We suggest that $A$. aspera causes a dose-related transient cardiovascular toxicity, 14. Phytochemical investigation of Combretum hartmannianum leaves, and bark revealed the presence of flavoniods similar to combretol and Ayanin, in addition to pentacyclic triterpenoids and acidic triterpenoids similar to those previously reported. Phenanthrene are expected among the compounds isolated from the plant. Phytochemical investigation of Commiphora myrrha (Nees) Engl. has afforded six new compounds identified, along with a known compound tria-cont-1-ene, (15).

\section{Materials and Methods}

\section{Plant material}

The plants were identified by the Herbarium at the Botany Department, Faculty of Science and Technology, Omdurman Islamic University; Voucher specimens of the plant material were deposited at the Botany Department, Omdurman Islamic 


\section{International Journal of Science and Research (IJSR) \\ ISSN (Online): 2319-7064 \\ Index Copernicus Value (2013): 6.14 | Impact Factor (2015): 6.391}

University. The plants used in this study were collected from screening. Plants screened were listed in (Table 1) with their different parts of Sudan. All the plant materials were carefully botanical names, families, vernacular names and chemical examined for the way of application and the diseases there constituents.

were claimed to care were obtained from the local herbalists

and recorded, then subjected to antimicrobial activity

Table 1: Plants selected for Antimicrobial studies:

\begin{tabular}{|c|c|c|c|c|}
\hline Name of plants & Family & Part used & Methanolic yield \% & Chemical constituents \\
\hline Acanthospermum hispidum & Asteracceae & Aerial parts & 11.35 & Sesquiterpenes, lactones, guaianolides (12) \\
\hline Achyranthes aspera & Amarathaceae & Seeds, stem, fruit & 7.94 & Saponins, alkaloids (16) \\
\hline Ambrosia maritima & Asteracceae & Whole plant & 0.60 & Coumarin, flavonoids, apigenin (17) \\
\hline Commiphora myrrh & Burseraceacea & Gum - stem & 4.94 & Essential oils, sesquiterpenes (18) \\
\hline Combretum hartmannianum & Combretaceae & Roots & 4.94 & Alkaloids, terpenes, flavonoids, phenolic(19) \\
\hline
\end{tabular}

\section{Preparation of the crude extracts:}

Each of the coarsely powdered plant material (50 g) exhaustively extracted for 20 hours with petroleum ether, ethyl acetate and methanol-water (80:20) respectively in Soxhlet apparatus. The extracts were filtered and evaporated under reduced pressure using rotary evaporator. The extracted plant material after extraction with each solvent was then air-dried, repacked in the Soxhlet. Each residue was weighed and the yield percentage was determined Table (1).

\section{Antimicrobial Activity}

The antimicrobial activity was determined by the agar well diffusion method against different strains of bacteria. Each test bacterium was spread onto sterile Muller-Hinton Agar (Hi-Media). A $6 \mathrm{~mm}$ diameter well was cut from the agar using a sterile cork-borer; subsequently each well was filled with $0.1 \mathrm{ml}$ of the plant extract. Sterile dimethyl sulfoxide (DMSO) served as negative.

\section{Antifungal Activity}

The fungal suspensions cultures were maintained on sabouraud dextrose agar, incubated at $25^{\circ} \mathrm{C}$ for 4 days. The fungal growth was harvested and washed with sterile normal saline, and the suspension was stored in the refrigerator until used.

\section{Preliminary Phytochemical Screening of methanolic fraction of $\boldsymbol{C}$. hartmannianum:}

The crude material was dissolved in methanol for TLC and run in different solvent system as mentioned in Table (2) then detected by different reagents for the qualitative analysis of phytochemical constituent. The crude material was also tested for their phytochemical constituents as mentioned in Table (3).

Table 2: Solvent system for TLC and spraying reagent

\begin{tabular}{|c|c|c|}
\hline No & Solvent Systems & Detection \\
\hline 1 & Chloroform: methanol (95:5) & $\begin{array}{c}\text { Vanillin in conc. Sulphuric } \\
\text { acid }\end{array}$ \\
\hline 2 & $\begin{array}{c}\text { Chloroform: methanol: Ethyl } \\
\text { acetate (+ 0.02ml Acetic acid) } \\
(60: 30: 10)\end{array}$ & $\begin{array}{c}\text { Dragendorff reagent } \\
\end{array}$ \\
\hline 3 & Toluene: Ethyl acetate (93:7) & Vanillin in conc. $\mathrm{H}_{2} \mathrm{SO}_{4}$ \\
\hline 4 & n- Butanal: Acetic Acid: & AlCl3 \\
& Water(4:1:5) & \\
\hline
\end{tabular}

Table 3: Phytochemical Screening

\begin{tabular}{|c|c|c|c|}
\hline S. No. & Test & Observation & Inference \\
\hline 1 & $\begin{array}{c}\text { Test Solution in alcohol + } \\
\text { a bit of magnesium and } \\
\text { two drops of concentrated } \\
\text { HCl and heat. }\end{array}$ & $\begin{array}{c}\text { Red or orange } \\
\text { red colour }\end{array}$ & $\begin{array}{l}\text { Presence of } \\
\text { flavonoids. }\end{array}$ \\
\hline 2 & $\begin{array}{c}\text { Test solution }+\mathrm{H}_{2} \mathrm{O} \text { and } \\
\text { shake. }\end{array}$ & Foamy lather & $\begin{array}{l}\text { Presence of } \\
\text { saponins }\end{array}$ \\
\hline 3 & $\begin{array}{c}\text { Test solution }+\mathrm{H}_{2} \mathrm{O}+ \\
\text { lead acetate }\end{array}$ & $\begin{array}{c}\text { White } \\
\text { precipitate }\end{array}$ & $\begin{array}{c}\text { Presence of } \\
\text { tannins }\end{array}$ \\
\hline 4 & $\begin{array}{l}\text { Test solution taken with } \\
\text { 2M HCL. Aq. layer } \\
\text { formed, decanted and to } \\
\text { which are added two } \\
\text { drops of Mayer's reagent. }\end{array}$ & $\begin{array}{l}\text { White } \\
\text { turbidity or } \\
\text { precipitate }\end{array}$ & $\begin{array}{l}\text { Presence of } \\
\text { alkaloids }\end{array}$ \\
\hline 5 & $\begin{array}{c}\text { Test solution }+ \\
\text { magnesium acetate } \\
\text { solution }\end{array}$ & Pink co lour & $\begin{array}{c}\text { Presence of } \\
\text { anthraquinon } \\
\text { e }\end{array}$ \\
\hline 6 & $\begin{array}{c}\text { Test solution in alcohol + } \\
\text { one drop of ferric } \\
\text { chloride (III). }\end{array}$ & Intense colour & $\begin{array}{c}\text { Presence of } \\
\text { phenolic }\end{array}$ \\
\hline
\end{tabular}

\section{Results}

In the present work in vitro evaluation was conducted for five extracts against four standard bacterial organisms Staphyococcus aureeus, Escherichia coli, Bacillus subtilis and Pseudomonas aeruginosa. The extracts were also tested for antifungal activity against two fungal strains Aspergillus niger and Candida albicans.

The results showed that methanolic extract (80\% in water) proved to be the most effective against all the tested becterial strains using cup-plate agar diffusion method, as shown in figures $1,2,3$. C. hartmannianum root extract were highly active against all the tested microbial strains, Bacillus subtilis was the most sensitive with $35 \mathrm{~mm}$ zone of inhibition, while the Pseudomonas aeruginosa showed the lowest susceptibility with $22 \mathrm{~mm}$ zone of inhibition.

C. hartmannianum roots petroleumether extract have amoderate activity with $19 \mathrm{~mm}$ zone against Bacillus subtilis, and showed weak inhibition $14 \mathrm{~mm}$ against the tested fungal strains. However, the ethyl acetate extract was highly active against all the tested strains. See figures 1, 2, 3 .

Investigated the antibacterial activity of four species belong to the Genus Combretum. They reported that, all methanolic and ethyl acetate extracts of Comtretum species possessed high activity against all tested organisms, figures 1, 2, 3 . 


\section{International Journal of Science and Research (IJSR) \\ ISSN (Online): 2319-7064 \\ Index Copernicus Value (2013): 6.14 | Impact Factor (2015): 6.391}

It is interesting to note that this plant is used in folkloric remedies in the treatment of external ulcers and fresh wounds medicine to treat jaundice and animals wounds. Many (20).

Combretum species have been used in Africa as folkloric

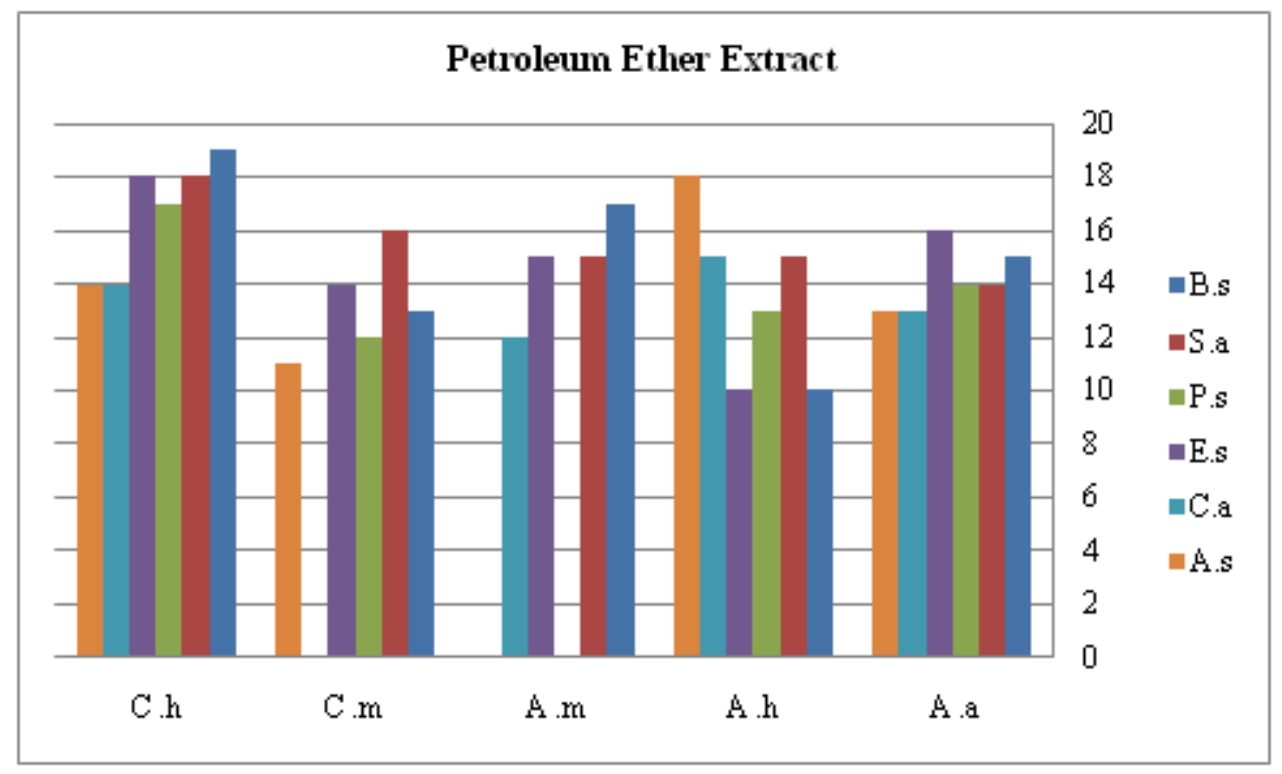

Figure 1

Standard bacteria: S.a: Staphylococcus aureus, B.s: Bacillus subtilis,

E.c: Escherichia coli, Ps.a: Pseudomonas aeruginosa, S.a: Staphylococcus aureus

Standard fungal: C.A: Candida albicans, A.s: Aspergillus niger

Plants study: A.a = Achyranthus aspera, A.h = Acanthospermum hispidum,

A. $m=$ Ambrosia maritima, $C . h=$ Combretum hartmannianum and C. $M=$ Commiphora myrrha .

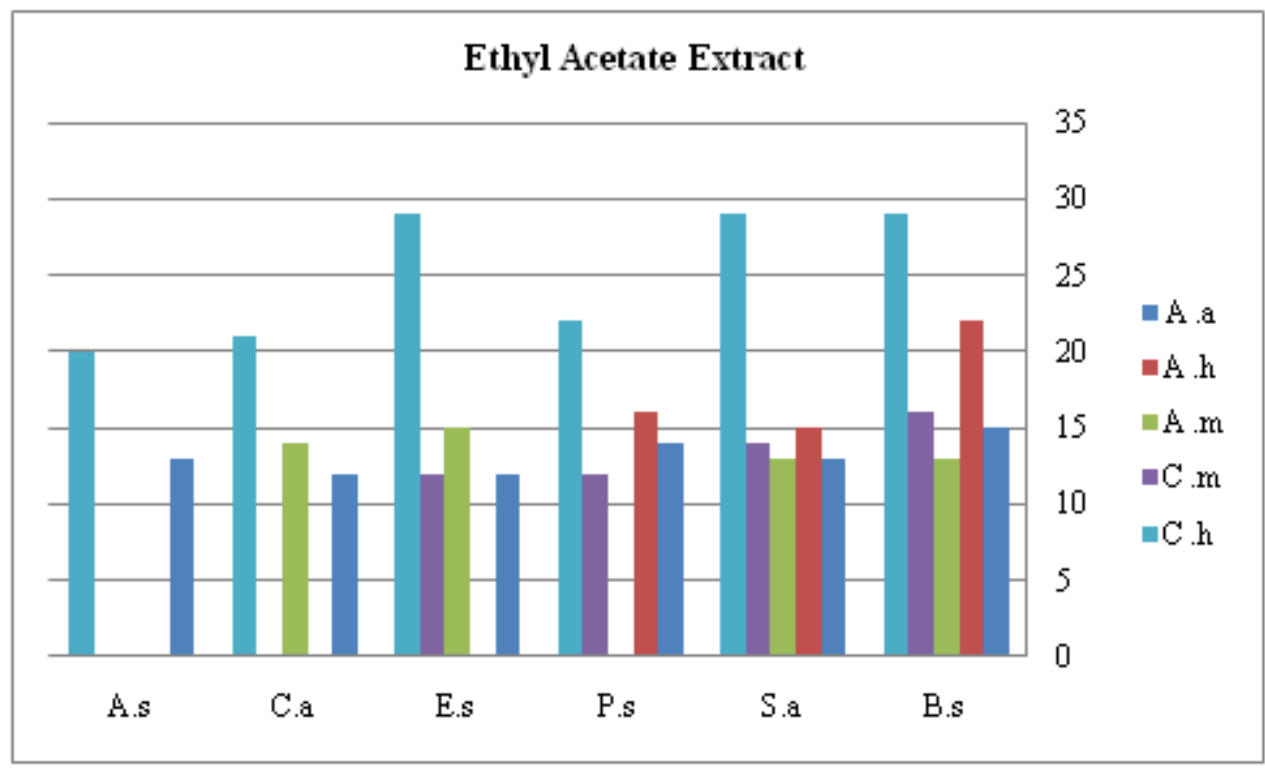

Figure 2 
International Journal of Science and Research (IJSR)

ISSN (Online): 2319-7064

Index Copernicus Value (2013): 6.14 | Impact Factor (2015): 6.391

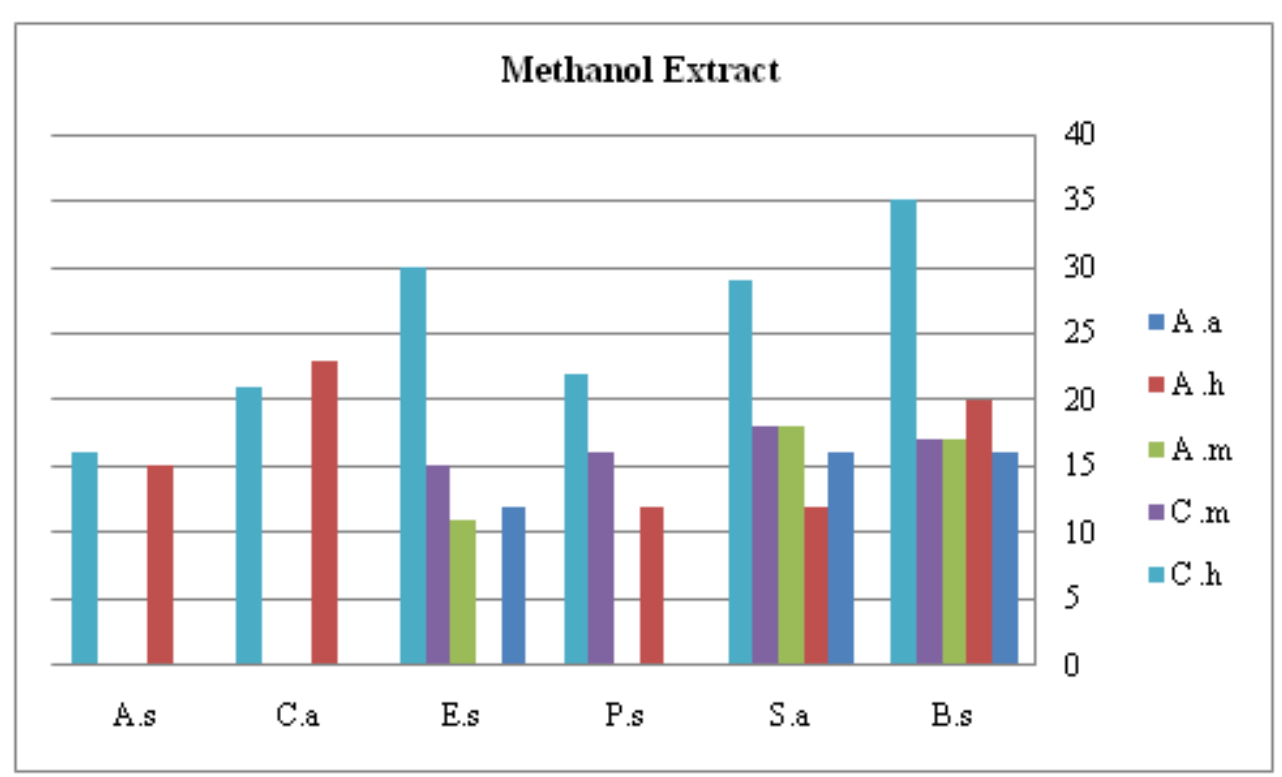

Figure 3

The result of TLC of C.hartmannianum:

compounds are terpenes because the solvent system is

Chromatographic investigation of separated compounds from nonpolar like terpenes.

Combretum hartmannianum roots extract (Solvent system:

dichloromethane: methanol 95:5). These separated

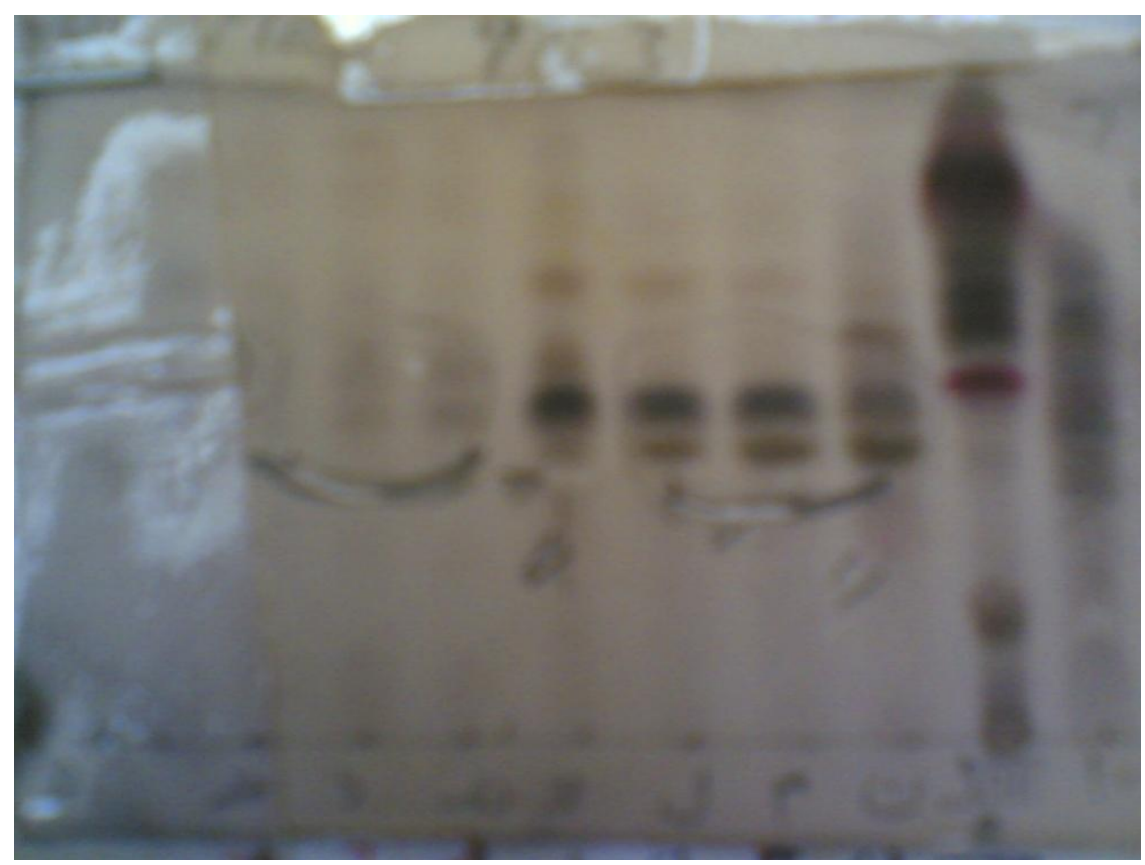

Figure 4

Figure 4: Chromatographic investigation of separated compounds are given with $R_{f}$ values Combretum hartmannianum roots extract (Solvent system: n-Butanol: Acetic acid:water 4:1:5). Table (7) below:

\begin{tabular}{|c|c|}
\hline Spots & $R f$ \\
\hline 1 & 0.35 \\
\hline 2 & 0.42 \\
\hline 3 & 0.5 \\
\hline 4 & 0.64 \\
\hline 5 & 0.75 \\
\hline
\end{tabular}




\section{International Journal of Science and Research (IJSR) \\ ISSN (Online): 2319-7064}

Index Copernicus Value (2013): 6.14 | Impact Factor (2015): 6.391

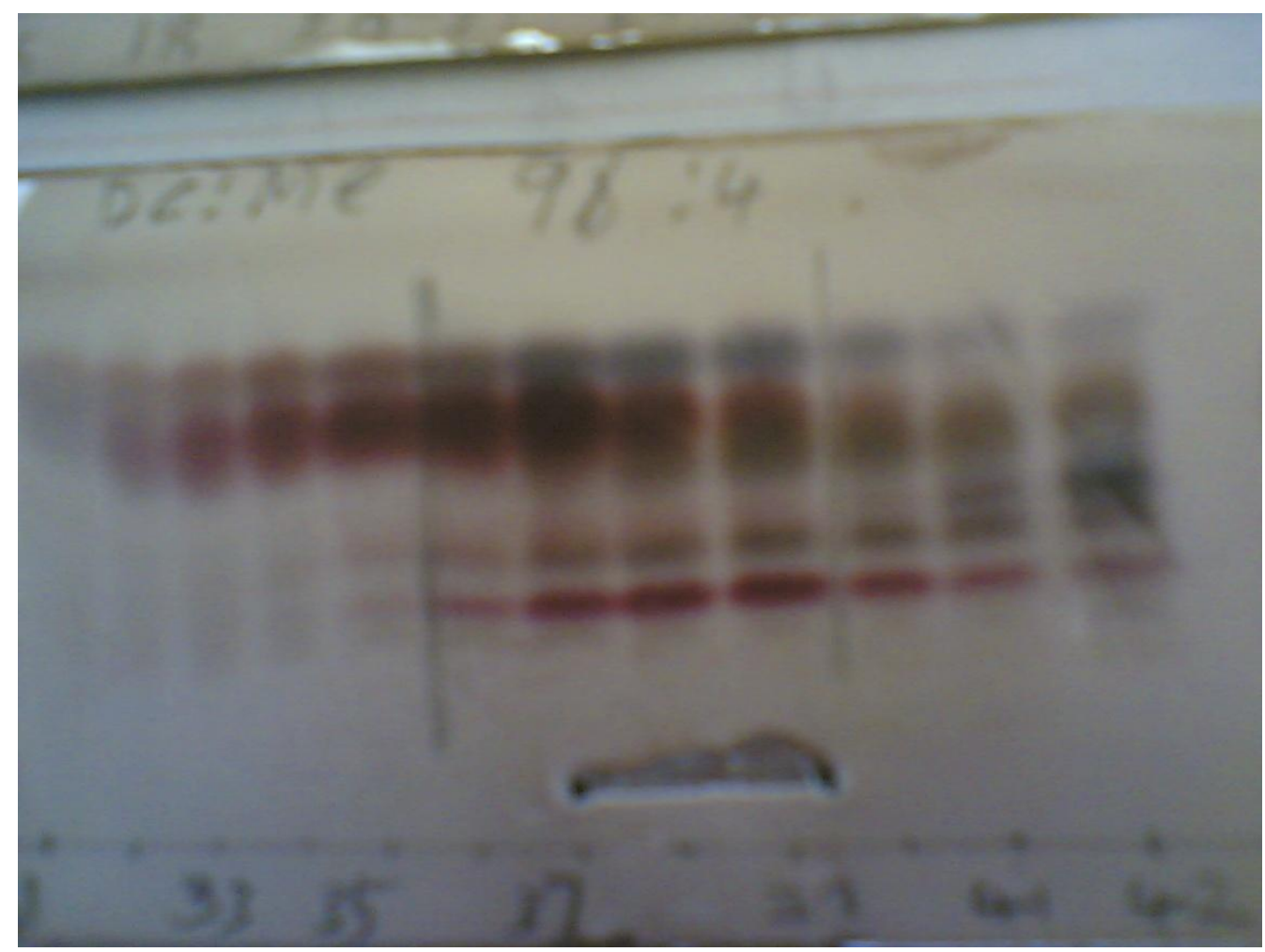

Figure 5

Spray Reagent: Vanillin in conc Sulphuric acid

Solvent system: n-Butanol: Acetic acid:water (4:1:5)

\section{Discussion}

The search for new substances with high antibacterial properties has been one of the most intensive efforts of this time. It is known that plant produce certain chemicals which are naturally toxic to bacteria but not to humans. Extracts of various Sudanese medicinal plants have been reported to possess antibacterial activity $(21,22,23)$. It is an established fact that intensive use of antibiotics is often followed by the development of resistantce strains. Because of this drug resistance, the search for new antibiotics continues unabated increase of microbial resistance is a world health problem (24). Development of new antibacterial principles to substitute with inefficient ones is a major weapon to combat the problem. Although the nature and number of active antibacterial principles involved in each extract of the present study are not clear, the broad spectra of activity of several plant extracts especially against Staphylococcus aureus, Escherichia coli, Pseudomonas aeruginosa.

In this study the polar extracts of Combretum hartmannianum roots (methanol extract) exhibited promising antibacterial activity against all tested bacterial strains and high activity against C.albicans fungi.

Compared to Gentamicin $(20 \mathrm{Mg} / \mathrm{ml})$, the petroleum ether extract of Combretum hartmannianum roots have the same spectrum (MIC $=18 \mathrm{mg} / \mathrm{ml}$ ) against Escherichia coli, and in some cases better level of antibacterial activity, also compared to Tetracycline $(40 \mathrm{Mg} / \mathrm{ml})$, the ethyl acetate extract of Ethulia conyzoides whole plant exhibited a broader spectrum (MIC =31Mg/ml) against Staphylococcus aureus.
The phytochemical study indicated the presence of phonelic flavonoids, saponins, tannins, alkaloids, phenolic compounds, in Combretum hartmannianum which could be be antimicrobial agents. This agree previous findings of (Grayer et al) 24 who reported that plants are effective as an antifungal.

Saponin has the property of precipitating and coagulating red blood cells. Some of the characteristics of saponins include formation of foams in aqueous solutions, cholesterol binding properties and bitterness.

Pure isolated alkaloids and their synthetic derivatives are used as basic medicinal agents for their analgesic, antispasmodic and bactericidal effects. They exhibit marked physiological activity when administered to animals. Flavonoids, on the other hand are potent water-soluble antioxidants and free radical scavengers, which prevent oxidative cell damage, have strong anticancer activity. Flavonoids in intestinal tract lower the risk of heart disease. As antioxidants, flavonoids from candidate plants provide anti-inflammatory activity. Tannins have stringent properties, hasten the healing of wounds and inflamed mucous membranes. These may be, explain why traditional healers in central Sudan treating wounds and burns.

\section{Conclusion}

In an ethnophamacological survey, extracts of the five medicinal plants were tested against four standard bacterial strains: Staphylococcus aureus (ATCC 25923), Bacillus subtilis (NCTC 8236), Escherichia coli (ATCC 25922), Pseudomonas aeruginosa (ATCC 27853), and against two fungal: As.niger and C.albicans. 


\section{International Journal of Science and Research (IJSR) \\ ISSN (Online): 2319-7064 \\ Index Copernicus Value (2013): 6.14 | Impact Factor (2015): 6.391}

The methanolic and ethyl acetate extract of $C$. hartmannianum was the most active of all tested extracts whole plants. The most antibcterially active plants were Combretum hartmannianum and Acanthospermum Hispidium, whereas the least active plant was Achyranthes aspera.

The present study is divided into two parts. part one include the study of antimicrobial and inhibitory activity of the extracts, part two includes phytochemical studies of candidate medicinal plant species that explain preliminary phytochemical analysis: flavonoids, saponins, tannins, alkaloids, percentage yield of the extracted candidate plant species by methanol (80\%). chromatographic examinations (TLC). The methanolic extract of C.hartmanninum was found to contain alkaloids. Tannins the results of chromatographic examinations indicating the probability of huge compounds are in C.hartmanninum root extracts should be isolated for further studing.

\section{References}

[1] Stokestad, E. L. R., Jukes, T. H., Pierce, J. 1949. The multiple nature of the animal protein factor. Journal of Biological Chemistry. 180:647-54.

[2] Preston, R. L. 1987. The role of animal drugs in food animal production. Symposium on Animal Drug UseDollars and Sense 1987, Washington, DC, USA. pp. 12734.

[3] Gaskins, H. R., Collier, C. C. \& Anderson, D. B. 2002. Antimicrobial agents as growth promotants: mode of action. Animal Biotechnology. 13:29-42.

[4] Wierup, M. 2001. The Swedish experience of the 1986 year ban of Antimicrobial growth promoters, with special reference to animal health, disease prevention, productivity, and use of Antimicrobial agents. Microbial Drug Resistance. 7:183-90.

[5] Dole, C. (2004) In:The shadows of medicinal and modernity medicinal integration and secular histories of Religious healing in Turky. J.Cult.Med.Psychiatry, Vo.28, No.3, 255-80.

[6] WHO (2002) WHO Global Strategy for Containment of Antimicrobial Resistance.

[7] Silva Junior, A.A, Vizotto, Z. J., Giorgi, Macedo, S.G and Matalka, K.Z.(2005) the antimicrobial activities of Psidium guajava and Juglans regia leaf extracts to acnedeveloping organisms.Am J clin Med 33: 197-205.

[8] Distasi LC (1996) Arte, ciência e magia. In LC Di Stasi, CA Hiruma-Lima (eds), J.Plantas Medicinais: Arte e Ciência, Unesp, São Paulo, p. 15-21.

[9] Holtz, F.B.; Pessini, G.L.;Sanches, N.R.; Cortez, D.A.G.; Nakamura, C.V. and Dias filho, B.P. (2002) Screening of some plants used in the Brazilian flok medicin for the treatment of infection diseases. J.Mem inst Oswaldo cruz 29:1027-1031.

[10] Sher A. (2009). Antimicrobial activity of natural products from medicinal plants. Gomal J Med Sci., 7(1):72- 78.

[11]El-egami, AA; Almagboul, AZ,; Omer, MEA., ElTohami, MS(1998). Sudanese Plants used in Folkloric Medicine: Screening for Antibacterial Activity.Part X.Fitoterapia. 69:4, 369-373.
[12] Voll E, Franchini JC, Da Cruz RT, Gazziero DL, Brighenti AM, Adegas FS (2004) J Chem Ecol. Jul;30(7):1467-75.

[13] Sandhyakumary K (2002). Indian J Exp Biol. Nov; 40(11):1307-9.

[14]Han ST, Un CC (2003). Vet Hum Toxicol. Aug;45(4):212-3.

[15] Ahmed F, Ali M, Singh O, (2006). Phytochemistry Research Laboratory Aug;61(8):728-731).

[16]Bagavan A, Rahuman AA, Kamaraj C, Geetha K(2005). Parasitol Res. Jun; 103(1):223-9.).

[17] Grace MH (2002). Phytother Res.Mar;16(2):183-5) Chemistry of Natural and Microbial Products Department, National Research Centre, Dokki, Cairo, Egypt.

[18] Kikuzaki H, and et al (2001). J Nat Prod. Department of Food Science, Rutgers University, New Brunswick, New Jersey 08901, USA. 64(11):1460-2.

[19] Farnsworth NR, ed. NAPRALERT database. 2001 Chicago, IL, University of Illinois at Chicago, 10 January 2001 production (an online database available directly through the University of Illinois at Chicago or through the Scientific and Technical Network (STN) of Chemical Abstracts Services).

[20] Hosstettmann, K; Chinyanganya, F.;Maillad, M.; Wol Fender, J.L (1996).Chemistry Biological and pharmalogical properties of African medical plants.Proceeding of the first international IODsymposium Victoria Falls, Zimbabwe University of Zimbabwe publication 1996.

[21] Omer, M.E.A., Al-magboul A.Z. and El Egami A. (1997). Sudanese Plants Used in Folkloric Medicine Screening for Antibacterial Activity. part V11.68(6): 549-554.

[22]El-egami, AA; Almagboul, AZ,; Omer, MEA., El Tohami, MS(2001). Sudanese Plants used in Folkloric Medicine: Screening for Antibacterial Activity.Part X. Fitoterapia. 72, 810-817.

[23]El-kamali H.H., Hamza, M.A and El-amir, M.Y.(2005). Antibacterial Activity of essential oil $C$ ymbopogon nervatus.Inflorescence. Accepted for publication in Fitoterapia.

[24] Gerding, D.N., Larson, T.A. and Haghes, R.A.(1991). Antibaterial Agents Chemother; 35: 1248. 